\title{
Penerapan Algoritma ELECTRE pada Pemilihan Cream Pelembab Berdasarkan Konsumen
}

\author{
Agus Perdana Windarto ${ }^{1, *}$, Wida Prima Mustika ${ }^{2}$ \\ ${ }^{1}$ Program Studi Sistem Informasi, STIKOM Tunas Bangsa, Pematangiantar, Indonesia \\ ${ }^{2}$ Prodi Sistem Informasi, STMIK Nusa Mandiri, Jakarta, Indonesia \\ Email: 1," agus.perdana@amiktunasbangsa.ac.id, ${ }^{2}$ wida.wpm@ @usamandiri.ac.id \\ *) Email Penulis Korespondensi: agus.perdana@amiktunasbangsa.ac.id
}

\begin{abstract}
Abstrak-Tujuan dari penelitian adalah untuk merekomendasikan pemilihan cream pelembab dengan menggunakan teknik perangkingan sistem pendukung keputusan yang dilihat dari penilaian konsumen. Penelitian ini dilakukan di kota pematangsiantar. Data diperoleh dengan cara observasi kebeberapa toko untuk memastikan ketersediaan cream pelembab, wawancara serta observasi kepada 250 konsumen yang dilakukan secara acak saat mereka melakukan transaksi pembelian cream pelembab. Dalam hal ini penelitian ini perlu dilakukan mengingat pelembab merupakan sebuah obat yang digunakan untuk membuat kulit wajah terasa lembab karena dengan kulit yang terasa lembab akan membuat perempuan terhindar dari berbagai masalah seperti komedo dan terhindar dari jerawat. Menjaga kulit wajah tetap lembab dan bebas minyak adalah hal yang tidak mudah untuk dilakukan penggunanya. Selain itu banyaknya produk cream pelembab yanga da saat ini membuat banyak perempuan bingung dalam memilih cream pelembab. Oleh karena itu peneliti menggunakan Sistem Pendukung Keputusan (SPK) dengan algoritma ELECTRE dalam merekomendasikan pemilihan cream pelembab berdasarkan penilaian konsumen. Dalam hal ini peneliti menggunakan beberapa kriteria penilaian antara lain: harga produk (C1), efek samping pemakaian (C2), kualitas produk (C3), komitmen pelanggan (C4), kepercayaan pelanggan (C5) dan reaksi pemakaian (C6). Sedangkan alternatif yang digunakan antara lain: Citra Hazeline (A1), Fair \& Lovely (A2), Garnier (A3), Olay (A4), Sariayu (A5) dan Wardah (A6). Hasil dari penilaian dengan menggunakan metode ELECTRE adalah Fair \& Lovely (A2) dan Wardah (A6) sebagai rekomendasi cream pelembab terbaik berdasarkan pilihan konsumen.
\end{abstract}

Kata Kunci: Metode ELECTRE, Sistem Pendukung Keputusan, Cream Pelembab, Konsumen, Pematangsiantar.

\begin{abstract}
The aim of the study is to recommend the selection of a moisturizing cream using a decision support system ranking technique seen from consumer ratings. This research was conducted in the city of Pematangsiantar. Data obtained by observation to several stores to ensure the availability of moisturizing cream, interviews and observations to 250 consumers who were randomly conducted when they made a transaction to purchase a moisturizing cream. In this case, this research needs to be done considering that moisturizer is a drug used to make facial skin feel moist because with skin that feels moist will make women avoid various problems such as blackheads and acne. Keeping facial skin moist and oil free is not an easy thing for users to do. In addition, the number of moisturizing cream products that are currently making many women confused in choosing a moisturizing cream. Therefore researchers used a Decision Support System (SPK) with the ELECTRE algorithm in recommending the selection of a moisturizing cream based on consumer ratings. In this case the researchers used several assessment criteria including: product price (C1), side effects of usage (C2), product quality (C3), customer commitment (C4), customer trust (C5) and usage reaction (C6). While the alternatives used include: Citra Hazeline (A1), Fair \& Lovely (A2), Garnier (A3), Olay (A4), Sariayu (A5) and Wardah (A6). The results of the assessment using the ELECTRE method are Fair \& Lovely (A2) and Wardah (A6) as the best moisturizing cream recommendations based on consumer choice.
\end{abstract}

Keywords: ELECTRE Method, Decision Support System, Moisturizing Cream, Consumers, Pematangsiantar.

\section{PENDAHULUAN}

Pelembab wajah merupakan salah satu bentuk perawatan wajah yang sering digunakan oleh perempuan. pelembab wajah biasanya terdiri dari berbagai macam mineral dan vitamin serta campuran dari air yang dapat membantu melembabkan wajah. Pelembab wajah dapat berupa cream, yang juga sering dikenal dengan nama day cream. Saat ini, pelembab wajah banyak beredar di berbagai toko-toko kosmetik dan juga pasar swalayan di sekitar kita. merk dari pelembab wajah pun bervariasi, ada yang berasal dari merk yang terkenal, dan ada pula yang merupakan pelembab wajah home made (produk rumahan). Dewasa ini banyak vendor menawarkan produk kecantikan mereka baik mulai dari harga termurah sampai termahal. Hal ini menjadi dilema bagi setiap perempuan dalam memilih cream pelembab baik dari segi harga maupun kualitas. Banyak produk cream pelembab dengan harga mahal namun tidak menjamin kualitas dari produk tersebut dan sebahagian cream pelembab dengan harga terjangkau memiliki kualitas yang menjanjikan. Setiap perempuan memiliki tingkat sensitivitas kulit yang berbeda. Bagi perempuan yang memiliki tingkat sensitivitas sangat tinggi harus berhatihati dalam memilih cream pelembab yang cocok terhadap jenis kulitnya karena apabila salah dalam memilih cream pelembab dapat menyebabkan iritasi dan sebagainya. Bahkan ada produk yang membuat perempuan menjadi ketergantungan terhadap cream pelembab tersebut. Dengan menggunakan cream pelembab kulit dapat terhindar dari efek sinar UVA dan UVB, menghindari kulit kering, menghilangkan flek hitam pada wajah, mencerahkan kulit wajah tanpa minyak berlebihan. Penelitian ini dilakukan di kota Pematangsiantar yang bertujuan untuk merekomendasikan pemilihan cream pelembab dengan menggunakan teknik penyelesaian di bidang ilmu komputer yang dilihat dari penilaian konsumen. Banyak cabang ilmu komputer yang dapat menyelesaikan permasalahan tersebut, antara lain Sistem Pendukung Keputusan (SPK) [1]-[4], Sistem Pakar [5], 
Datamining [6]-[8], Jaringan Saraf Tiruan (JST) [9]-[13], Fuzzy [14], dan lain-lain. Setiap cabang ilmu memiliki karakteristik masing-masing. Berdasarkan permasalahan diatas, dibutuhkan sebuah sistem pendukung keputusan yang dapat memberikan rekomendasi pemilihan cream pelembab berdasarkan pilihan konsumen.

Sistem Pendukung Keputusan (SPK) merupakan salah satu cara mengorganisir informasi yang dimaksudkan untuk digunakan dalam membuat keputusan [15]. Pengambilan keputusan pada dasarnya merupakan suatu bentuk pemilihan berbagai alternative dan tindakan yang mungkin dipilih dimana prosesnya melalui suatu mekanisme tertentu dengan harapan dapat menghasilkan keputusan terbaik sesuai kriteria yang digunakan. Salah satu metode pengambilan keputusan yang dimaksud adalah metode ELECTRE [21]. Metode ELECTRE merupakan salah satu metode pengambilan keputusan multikriteria berdasarkan pada konsep outranking dengan menggunakan perbandingan berpasangan dari alternatif-alternatif berdasarkan setiap kriteria yang sesuai[22]. Ada beberapa penelitian terdahulu yang menggunakan metode ELECTRE dalam menyelesaikan kasus yang bersifat multikriteria. Salah satunya adalah penelitian [23] yang berjudul "Implementation of Elimination and Choice Expressing Reality (ELECTRE) Method in Selecting the Best Lecturer". Penelitian ini membahas pengukuran indeks kinerja dosen di sebuah perguruan tinggi. Indeks kinerja menjadi dasar bagi dosen universitas dalam menentukan dan merekomendasikan dosen terbaik yang dimiliki oleh universitas. Solusi tepat untuk masalah yang dihadapi oleh pimpinan universitas sebagai pengambil keputusan untuk mempertimbangkan beberapa kriteria yang berkaitan dengan penentuan dosen komputer terbaik adalah metode ELECTRE. Berdasarkan hal tersebut, teknik perangkingan dengan metode ELECTRE akan menjadi solusi yang diberikan untuk pemilihan cream pelembab.

\section{METODE PENELITIAN}

Penelitian ini menggunakan metode ELECTRE untuk membuat SPK penentuan pemilihan cream pelembab berdasarkan penilaian konsumen. Penelitian ini menggunakan data kuantitatif yang dilakukan di kota pematangsiantar. Pengumpulan data pada penelitian dilakukan dengan cara observasi kebeberapa toko untuk memastikan ketersediaan cream pelembab, wawancara serta pemberian angket kepada 250 konsumen yang dilakukan secara acak saat mereka melakukan transaksi pembelian cream pelembab. Dalam penentuan cream pelembab memiliki beberapa kriteria dan alternatif yang digunakan. kriteria penilaian antara lain: harga produk (C1), efek samping pemakaian (C2), kualitas produk (C3), komitmen pelanggan (C4), kepercayaan pelanggan (C5) dan reaksi pemakaian (C6). Sedangkan alternatif yang digunakan antara lain: Citra Hazeline (A1), Fair \& Lovely (A2), Garnier (A3), Olay (A4), Sariayu (A5) dan Wardah (A6). Berikut adalah gambaran konseptual mengenai proses pengambilan keputusan yang ditunjukan pada (Gambar 1), dibawah ini:

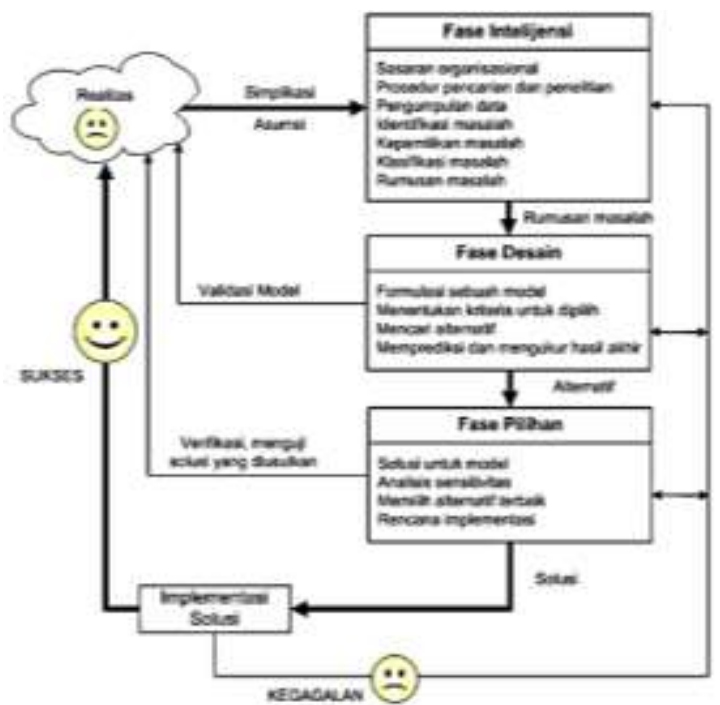

Gambar 1. Proses Pemodelan Pengambilan Keputusan

Pada dasarya metodologi penelitian terdiri dari tahapan-tahapan proses penelitian atau urutan-urutan/ langkah yang harus dilakukan oleh peneliti dalam menjalankan penelitian. Secara garis besar langkah-langkah penelitian dapat dilihat dari Flowchart dibawah ini: 

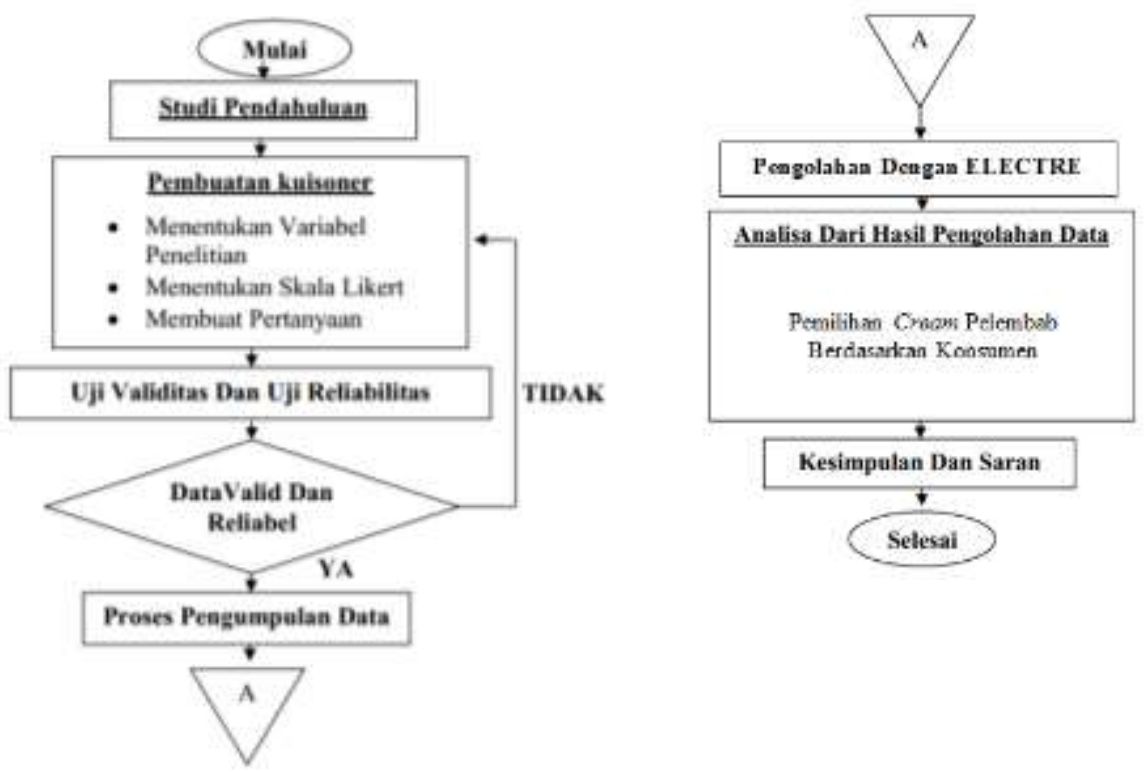

Gambar 2. Flowchart Metodologi Penelitian

\subsection{Metode ELECTRE (Elemination and Chioce Translation Reality)}

Sistem Pendukung Keputusan (SPK) merupakan sebuah sistem untuk mendukung para pengambil keputusan manajerial dalam situasi situasi tertentu dimana SPK dapat menjadi alat untuk memperluas kapabilitas mereka, namun tidak untuk menggantikan penilaian mereka [12][13]. Salah satu bagian dari SPK adalah Metode ELECTRE yang merupakan metode pengambilan keputusan multikriteria yang digunakan pada kondisi dimana alternatif yang kurang sesuai dengan kriteria, maka dieliminasi, dan alternatif yang sesuai dapat dihasilkan [14][24]-[26].

\section{HASIL DAN PEMBAHASAN}

Dalam perhitungan ELECTRE dibutuhkan data data pendukung seperti data alternatif yang ditunjukkan pada tabel 1 serta data kriteria dan bobot yang ditunjukkan pada tabel 2 .

Tabel 1. Data Alternatif

\begin{tabular}{lll}
\hline No. & Alternatif & Nama Produk \\
\hline 1 & A1 & Citra Hazeline \\
2 & A2 & Fair \& Lovely \\
3 & A3 & Garnier \\
4 & A4 & Olay \\
5 & A5 & Sariayu \\
6 & A6 & Wardah \\
\hline
\end{tabular}

Tabel 2. Tabel Kriteria Dan Bobot

\begin{tabular}{llll}
\hline No & Kriteria & Nama & Bobot \\
\hline 1. & C1 & Harga & 0,1 \\
2. & C2 & Efek Samping & 0,25 \\
3. & C3 & Kualitas Produk & 0,15 \\
4. & C4 & Komitmen Pelanggan & 0,05 \\
5. & C5 & Kepercayaan Pelanggan & 0,1 \\
6. & C6 & Reaksi Pemakaian & 0,35 \\
\hline
\end{tabular}

Tabel 3. Tingkat Kepentingan

\begin{tabular}{lll}
\hline No & Nilai & Keterangan \\
\hline 1. & 0,9 & Sangat baik \\
2. & 0,75 & Baik \\
3. & 0,5 & Netral \\
4. & 0,25 & Tidak Baik \\
\hline
\end{tabular}


Tabel 4. Menentukan Rating Kecocokan Setiap Alternatif Pada Setiap Kriteria

\begin{tabular}{lllllll}
\hline Alternatif & C1 & C2 & C3 & C4 & C5 & C6 \\
\hline A1 & 0,75 & 0,43 & 0,82 & 0,6 & 0,75 & 0,76 \\
A2 & 0,59 & 0,4 & 0,69 & 0,65 & 0,7 & 0,66 \\
A3 & 0,68 & 0,4 & 0,71 & 0,54 & 0,64 & 0,63 \\
A4 & 0,71 & 0,42 & 0,67 & 0,68 & 0,44 & 0,56 \\
A5 & 0,71 & 0,58 & 0,62 & 0,45 & 0,71 & 0,57 \\
A6 & 0,66 & 0,42 & 0,75 & 0,65 & 0,65 & 0,65 \\
\hline
\end{tabular}

Proses menerapkan metode ELECTRE dapat dilihat di bawah ini.

1. Normalisasi matriks keputusan. Pada tahap ini setiap atribut diubah menjadi nilai yang comparable:

$\mathrm{R}_{11}=X_{11} / \sqrt{ } x_{11}^{2}+x_{12}^{2}+x_{13^{2}}+x_{14}^{2}+x_{15^{2}}+x_{16}^{2}$

$$
\begin{aligned}
& \mathrm{R}_{11}=0,75 / \sqrt{ } 0,75^{2}+0,59^{2}+0,68^{2}+0,71^{2}+0,71^{2}+0,66^{2} \\
& \mathrm{R}_{11}=0,75 / \sqrt{ } 2,79 \\
& \mathrm{R}_{11}=0,75 / 1,6783 \\
& \mathrm{R}_{11}=0,4468
\end{aligned}
$$

Dan seterusnya sampai $X_{6}$ sehingga mendapat matriks $R$ hasil normalisasi:

Tabel 5. Hasil Normalisasi Matriks Keputusan

\begin{tabular}{llllll}
\hline \multicolumn{7}{c}{$\mathrm{R}($ Normalisasi) } \\
\hline 0,44687 & 0,3935 & 0,46965 & 0,40811 & 0,46672 & 0,48347 \\
0,35154 & 0,36605 & 0,3952 & 0,44212 & 0,43561 & 0,41985 \\
0,40516 & 0,36605 & 0,40665 & 0,3673 & 0,39827 & 0,40077 \\
0,42304 & 0,38435 & 0,38374 & 0,46252 & 0,27381 & 0,35624 \\
0,42304 & 0,53077 & 0,3551 & 0,30608 & 0,44183 & 0,3626 \\
0,39325 & 0,38435 & 0,42956 & 0,44212 & 0,40449 & 0,41349 \\
\hline
\end{tabular}

2. Pembobotan pada matriks yang telah dinormalisasikan. Matriks $V$ merupakan hasil perkalian dari $R$ dengan $W$ (bobot), dimana $W=\{0,1,0,25,0,15,0,05,0,1,0,35\}$. Hasil dari perkalian bobot prefensi setiap kriteria dengan matriks keputusan yang telah dinormalisasi dapat dilihat pada matriks dibawah ini:

Tabel 6. Pembobotan Pada Matriks setelah normalisasi

\begin{tabular}{llllll}
\hline \multicolumn{5}{c}{ V(Normalisasi*bobot)(R*W) } \\
\hline 0,04469 & 0,09838 & 0,07045 & 0,02041 & 0,04667 & 0,16921 \\
0,08788 & 0,09151 & 0,05928 & 0,02211 & 0,04356 & 0,14695 \\
0,06077 & 0,09151 & 0,061 & 0,01836 & 0,03983 & 0,14027 \\
0,02115 & 0,09609 & 0,05756 & 0,02313 & 0,02738 & 0,12468 \\
0,0423 & 0,13269 & 0,05327 & 0,0153 & 0,04418 & 0,12691 \\
0,13764 & 0,09609 & 0,06443 & 0,02211 & 0,04045 & 0,14472 \\
\hline
\end{tabular}

3. Menentukan himpunan concordance dan discordance index.

a. Menentukan himpunan concordance:

$$
\begin{aligned}
& C 12=V 11 \geq V 21=0,04469 \geq 0,08788 \\
& V 12 \geq V 22=0,07045 \geq 0,09151 \\
& V 13 \geq V 23=0,07045 \geq 0,05928 \\
& V 14 \geq V 24=0,02041 \geq 0,02211 \\
& V 15 \geq V 25=0,04667 \geq 0,04356 \\
& V 16 \geq V 26=0,16921 \geq 0,14695
\end{aligned}
$$

Dan seterusnya hingga $C_{65}$, Sehingga menghasilkan himpunan concordance pada tabel berikut :

Tabel 7. Himpunan Concordance

\begin{tabular}{ll}
\hline $\mathrm{C}$ & Himpunan \\
\hline $\mathrm{C}_{12}$ & $\{1,2,3,5,6\}$ \\
$\mathrm{C}_{13}$ & $\{1,2,3,4,5,6\}$ \\
$\mathrm{C}_{14}$ & $\{1,2,3,5,6\}$ \\
$\mathrm{C}_{15}$ & $\{1,3,4,5,6\}$ \\
\hline
\end{tabular}


Available Online at https://ejurnal.stmik-budidarma.ac.id/index.php/mib DOI 10.30865/mib.v4i1.1966

\begin{tabular}{ll}
\hline $\mathrm{C}_{16}$ & $\{1,2,3,5,6\}$ \\
$\mathrm{C}_{21}$ & $\{4\}$ \\
$\mathrm{C}_{23}$ & $\{2,4,5,6\}$ \\
$\mathrm{C}_{24}$ & $\{3,5,6\}$ \\
$\mathrm{C}_{25}$ & $\{3,4,6\}$ \\
$\mathrm{C}_{26}$ & $\{3,5,6\}$ \\
$\mathrm{C}_{31}$ & $\{0\}$ \\
$\mathrm{C}_{32}$ & $\{1,2,3\}$ \\
$\mathrm{C}_{34}$ & $\{3,5,6\}$ \\
$\mathrm{C}_{35}$ & $\{3,4,6\}$ \\
$\mathrm{C}_{36}$ & $\{1\}$ \\
$\mathrm{C}_{41}$ & $\{4\}$ \\
$\mathrm{C}_{42}$ & $\{1,2,4\}$ \\
$\mathrm{C}_{43}$ & $\{1,2,4\}$ \\
$\mathrm{C}_{45}$ & $\{1,3,4\}$ \\
$\mathrm{C}_{46}$ & $\{1,2,4\}$ \\
$\mathrm{C}_{51}$ & $\{2\}$ \\
$\mathrm{C}_{52}$ & $\{1,2,5\}$ \\
$\mathrm{C}_{53}$ & $\{1,2,5\}$ \\
$\mathrm{C}_{54}$ & $\{1,2,5,6\}$ \\
$\mathrm{C}_{56}$ & $\{1,2,5\}$ \\
$\mathrm{C}_{61}$ & $\{4\}$ \\
$\mathrm{C}_{62}$ & $\{1,2,3,4\}$ \\
$\mathrm{C}_{63}$ & $\{2,3,4,5,6\}$ \\
$\mathrm{C}_{64}$ & $\{2,3,5,6\}$ \\
$\mathrm{C}_{65}$ & $\{3,4,6\}$ \\
\hline
\end{tabular}

b. Menentukan himpunan discordance :

$$
\begin{aligned}
& D 12=V 11<V 21=0,04469<0,08788 \\
& V 12<V 22=0,07045<0,09151 \\
& V 13<V 23=0,07045<0,05928 \\
& V 14<V 24=0,02041<0,02211 \\
& V 15<V 25=0,04667<0,04356 \\
& V 16<V 26=0,16921<0,14695
\end{aligned}
$$

Dan seterusnya hingga $D_{65}$, Sehingga menghasilkan himpunan discordance pada tabel berikut :

Tabel 8. Himpunan Discordance

\begin{tabular}{ll}
\hline $\mathrm{D}$ & Himpunan \\
\hline $\mathrm{D}_{12}$ & $\{4\}$ \\
$\mathrm{D}_{13}$ & $\{0\}$ \\
$\mathrm{D}_{14}$ & $\{4\}$ \\
$\mathrm{D}_{15}$ & $\{2\}$ \\
$\mathrm{D}_{16}$ & $\{4\}$ \\
$\mathrm{D}_{21}$ & $\{1,2,3,5,6\}$ \\
$\mathrm{D}_{23}$ & $\{1,3\}$ \\
$\mathrm{D}_{24}$ & $\{1,2,4\}$ \\
$\mathrm{D}_{25}$ & $\{1,2,5\}$ \\
$\mathrm{D}_{26}$ & $\{1,2,3\}$ \\
$\mathrm{D}_{31}$ & $\{1,2,3,4,5,6\}$ \\
$\mathrm{D}_{32}$ & $\{4,5,6\}$ \\
$\mathrm{D}_{34}$ & $\{1,2\}$ \\
$\mathrm{D}_{35}$ & $\{1,2,5\}$ \\
$\mathrm{D}_{36}$ & $\{2,3,4,5,6\}$ \\
$\mathrm{D}_{41}$ & $\{1,2,3,5,6\}$ \\
$\mathrm{D}_{42}$ & $\{3,5,6\}$ \\
$\mathrm{D}_{43}$ & $\{3,5,6\}$ \\
$\mathrm{D}_{45}$ & $\{2,5,6\}$ \\
$D_{46}$ & $\{3,5,6\}$ \\
$\mathrm{D}_{51}$ & $\{1,3,4,5,6\}$ \\
$\mathrm{D}_{52}$ & $\{3,4,6\}$ \\
$D_{53}$ & $\{3,4,6\}$ \\
\hline &
\end{tabular}


Available Online at https://ejurnal.stmik-budidarma.ac.id/index.php/mib DOI $10.30865 /$ mib.v4i1.1966

\begin{tabular}{ll}
\hline $\mathrm{D}_{54}$ & $\{3,4\}$ \\
$\mathrm{D}_{56}$ & $\{3,4,6\}$ \\
$\mathrm{D}_{61}$ & $\{1,2,3,5,6\}$ \\
$\mathrm{D}_{62}$ & $\{5,6\}$ \\
$\mathrm{D}_{63}$ & $\{1\}$ \\
$\mathrm{D}_{64}$ & $\{1,4\}$ \\
$\mathrm{D}_{65}$ & $1,2,5\}$ \\
\hline
\end{tabular}

4. Menghitung matriks concordance dan discordance.

a. Menghitung concordance

$$
\begin{aligned}
\mathrm{C} 12 & =\mathrm{W} 1+\mathrm{W} 2+\mathrm{W} 3+\mathrm{W} 4+\mathrm{W} 5+\mathrm{W} 6 \\
& =0,1+0,25+0,15+0,05+0,1+0,35 \\
& =1
\end{aligned}
$$

dan seterusnya hingga $C_{65}$, Sehingga diperoleh matriks yaitu:

Tabel 9. Matriks Concordance

\begin{tabular}{lllllll}
\hline $\begin{array}{l}\text { Matriks } \\
\text { concordance }\end{array}$ & A1 & A2 & A3 & A4 & A5 & A6 \\
\hline A1 & - & 0,95 & 1 & 0,95 & 0,75 & 0,95 \\
A2 & 0,05 & - & 0,75 & 0,6 & 0,55 & 0,5 \\
A3 & 0 & 0,5 & - & 0,6 & 0,55 & 0,1 \\
A4 & 0,005 & 0,4 & 0,4 & - & 0,3 & 0,4 \\
A5 & 0,25 & 0,45 & 0,45 & 0,8 & - & 0,45 \\
A6 & 0,05 & 0,55 & 0,9 & 0,85 & 0,55 & - \\
\hline
\end{tabular}

b. Menghitung discordance

$D_{12}=\operatorname{Max}\{|0,02041-0,02211|\} / \operatorname{Max}\{|0,4469-0,08788| ;|0,09838-0,09151| ;|0,07045-0,05928| ; \mid 0,02041$ $0,02211|;| 0,04667-0,04356|;| 0,16921-0,14695 \mid\}$

$D_{12}=\operatorname{Max}\{|0,00171| \gamma / \operatorname{Max}\{|0,35902| ;|0,00687| ;|0,01117| ;|0,0017| ;|0,00311| ;|0,16921-0,02226|\}$

$D_{12}=|0,00171| /|0,35902|=0,00473$

dan seterusnya hingga $D_{65}$, Sehingga diperoleh matriks yaitu:

Tabel 10. Matriks Discordance.

\begin{tabular}{lllllll}
\hline $\begin{array}{l}\text { Matriks } \\
\text { concordance }\end{array}$ & A1 & A2 & A3 & A4 & A5 & A6 \\
\hline A1 & - & 0,03936 & 0 & 0,0611 & 0,81121 & 0,01729 \\
A2 & 1 & - & 1 & 1 & 1 & 1 \\
A3 & 1 & 1 & - & 0,5558 & 0,5558 & 0,5558 \\
A4 & 1 & 1 & 1 & - & 1 & 1 \\
A5 & 1 & 1 & 1 & 0,40617 & - & 1 \\
A6 & 1 & 0,26349 & 1 & 1 & 1 & - \\
\hline
\end{tabular}

5. Menentukan matriks dominan Concordance dan Discordance.

a. Menghitung matriks dominan concordance Threshold yang didapat dari penjumlahan seluruh elemen matriks dibagi ukuran matriks.

$C=(0,95+1+0,95+0,75+0,95+0,05+0,75+0,6+0,55+0,5+0+0,5+0,6+0,55+0,1+0,05+0,4+0,4+0,3+0,4$ $+0,25+0,45+0,45+0,8+0,45+0,05+0,55+0,9+0,85+0,55) / 6 *(6-1)=$

$C=15,65 / 30=0,52167$

Sehingga matriks dominan Concordance adalah

Tabel 11. Matriks Dominan Concordance

\begin{tabular}{lllllll}
\hline $\begin{array}{l}\text { Matriks Dominan } \\
\text { Concordance }\end{array}$ & A1 & A2 & A3 & A4 & A5 & A6 \\
\hline A1 & - & 1 & 1 & 1 & 1 & 1 \\
A2 & 0 & - & 1 & 1 & 1 & 0 \\
A3 & 0 & 0 & - & 1 & 1 & 0 \\
A4 & 0 & 0 & 0 & - & 0 & 0 \\
A5 & 0 & 0 & 0 & 1 & - & 0 \\
A6 & 0 & 1 & 1 & 1 & 1 & - \\
\hline
\end{tabular}

b. Menghitung matriks dominan discordance 


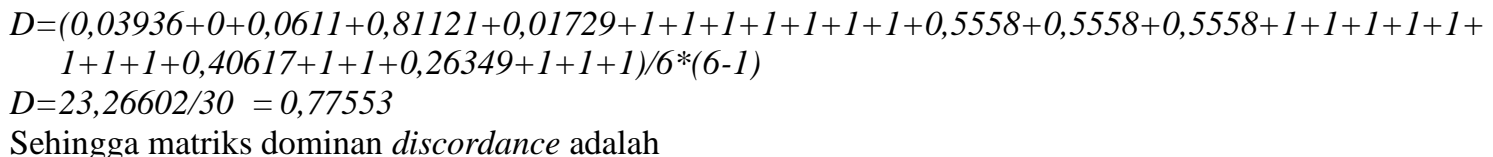

Tabel 12. Matriks Dominan discordance

\begin{tabular}{lllllll}
\hline $\begin{array}{l}\text { Matriks Dominan } \\
\text { Concordance }\end{array}$ & A1 & A2 & A3 & A4 & A5 & A6 \\
\hline A1 & - & 0 & 0 & 0 & 1 & 0 \\
A2 & 1 & - & 1 & 1 & 1 & 1 \\
A3 & 1 & 1 & - & 0 & 0 & 0 \\
A4 & 1 & 0 & 1 & - & 1 & 1 \\
A5 & 1 & 1 & 1 & 0 & - & 1 \\
A6 & 1 & 0 & 1 & 1 & 1 & - \\
\hline
\end{tabular}

6. Menentukan aggregate matriks untuk memberikan urutan pada pilihan alternative sehingga dalam matriks yang memiliki angka 1 dieliminasi. Dengan demikian, alternatif terbaik adalah alternatif yang mendominasi alternatif lainnya.

Tabel 13. Matriks Aggregate Dominance

\begin{tabular}{lllllll}
\hline A1 & - & 0 & 0 & 0 & 1 & 0 \\
A2 & 0 & - & 1 & 1 & 1 & 0 \\
A3 & 0 & - & - & 0 & 0 & 0 \\
A4 & 0 & - & 0 & - & 0 & 0 \\
A5 & 0 & - & 0 & 0 & - & 0 \\
A6 & 0 & - & 1 & 1 & 1 & - \\
\hline
\end{tabular}

7. Eliminasi alternatif yang less favourable.

Matriks $E$ memberikan urutan pilihan dari setiap alternatif, yaitu bila $e k l=1$ maka alternatif $A_{k}$ merupakan pilihan yang lebih baik daripada $A_{l}$. Sehingga baris dalam matriks $E$ yang memiliki jumlah $e_{k l}=1$ paling sedikit dapat dieliminasi. Dengan demikian alternatif terbaik adalah yang mendominasi alternatif lainnya. Hasil dari perhitungan dengan metode ELECTRE maka diperoleh peringkat yang paling tinggi $\mathrm{A}_{6}$ yaitu Wardah.

\section{KESIMPULAN}

Berdasarkan hasil penelitian dan pembahasan tentang sistem pendukung keputusan dalam merekomendasikan cream pelembab terbaik berdasarkan konsumen menggunakan metode electre dapat disimpulkan bahwa:

a) Metode ELECTRE dapat digunakan untuk menentukan jenis cream pelembab bagi konsumen.

b) Metode ELECTRE dapat diterapkan dalam kasus penentuan cream pelembab dengan mempertimbangkan beberapa kriteria antara lain: harga produk (C1), efek samping pemakaian (C2), kualitas produk (C3), komitmen pelanggan (C4), kepercayaan pelanggan (C5), dan reaksi pemakaian (C6).

c) Dari hasil penelitian ini dapat disimpulkan bahwa Wardah (A6) dan Fair \& Lovely (A2) yang menjadi rekomendasi cream pelembab terbaik berdasarkan konsumen.

\section{REFERENCES}

[1] K. F. Irnanda, F. N. Arifah, M. R. Raharjo, A. Arifin, and A. P. Windarto, "The selection of Calcium Milk Products that are appropriate for advanced age using PROMETHEE II Algorithm,” J. Phys. Conf. Ser., vol. 1381, no. 1, 2019, doi: 10.1088/1742-6596/1381/1/012070.

[2] S. R. Ningsih, R. Wulansari, D. Hartama, A. P. Windarto, and A. Wanto, "Analysis of PROMETHEE II Method on Selection of Lecturer Community Service Grant Proposals," J. Phys. Conf. Ser., vol. 1255, no. 1, pp. 1-7, 2019, doi: 10.1088/1742-6596/1255/1/012004.

[3] D. R. Sari, N. Rofiqo, D. Hartama, A. P. Windarto, and A. Wanto, "Analysis of the Factors Causing Lazy Students to Study Using the ELECTRE II Algorithm," J. Phys. Conf. Ser., vol. 1255, no. 1, 2019, doi: 10.1088/17426596/1255/1/012007.

[4] S. Sundari, Karmila, M. N. Fadli, D. Hartama, A. P. Windarto, and A. Wanto, "Decision Support System on Selection of Lecturer Research Grant Proposals using Preferences Selection Index,” J. Phys. Conf. Ser., vol. 1255, no. 1, pp. 1-8, 2019, doi: 10.1088/1742-6596/1255/1/012006.

[5] M. Silmi, E. A. Sarwoko, and Kushartantya, "Sistem Pakar Berbasis Web Dan Mobile Web Untuk Mendiagnosis Penyakit Darah Pada Manusia Dengan Menggunakan Metode Inferensi Forward Chaining," J. Masy. Inform., vol. 4, no. 7, pp. 31-38, 2011.

[6] A. P. Windarto, "Implementation of Data Mining on Rice Imports by Major Country of Origin Using Algorithm Using K-Means Clustering Method,” Int. J. Artif. Intell. Res., vol. 1, no. 2, pp. 26-33, 2017.

[7] A. P. Windarto, "Penerapan Data Mining Pada Ekspor Buah-Buahan Menurut Negara Tujuan Menggunakan K-Means Clustering," Techno.COM, vol. 16, no. 4, pp. 348-357, 2017. 
[8] B. Supriyadi, A. P. Windarto, T. Soemartono, and Mungad, "Classification of natural disaster prone areas in Indonesia using K-means,” Int. J. Grid Distrib. Comput., vol. 11, no. 8, pp. 87-98, 2018.

[9] Budiharjo, T. Soemartono, A. P. Windarto, and T. Herawan, "Predicting tuition fee payment problem using backpropagation neural network model," Int. J. Adv. Sci. Technol., vol. 120, pp. 85-96, 2018, doi: 10.14257/ijast.2018.120.07.

[10] A. P. Windarto, M. R. Lubis, and Solikhun, "Implementasi Jst Pada Prediksi Total Laba Rugi Komprehensif Bank Umum Konvensional Dengan Backpropagation,” J. Teknol. Inf. dan Ilmu Komput., vol. 5, no. 4, pp. 411-418, 2018, doi: $10.25126 /$ jtiik.201854767.

[11] A. P. Windarto, M. R. Lubis, and Solikhun, "Model Arsitektur Neural Network Dengan Backpropogation Pada Prediksi Total Laba Rugi Komprehensif Bank Umum Konvensional,” Kumpul. J. Ilmu Komput., vol. 5, no. 2, pp. 147-158, 2018.

[12] Sumijan, A. P. Windarto, A. Muhammad, and Budiharjo, "Implementation of Neural Networks in Predicting the Understanding Level of Students Subject," Int. J. Softw. Eng. Its Appl., vol. 10, no. 10, pp. 189-204, 2016.

[13] Budiharjo, T. Soemartono, A. P. Windarto, and T. Herawan, "Predicting School Participation in Indonesia using BackPropagation Algorithm Model," Int. J. Control Autom., vol. 11, no. 11, pp. 57-68, 2018.

[14] A. Wanto, "Analisis Penerapan Fuzzy Inference System (FIS) Dengan Metode Mamdani Pada Sistem Prediksi Mahasiswa Non Aktif (Studi Kasus: AMIK Tunas Bangsa Pematangsiantar)," in Seminar Nasional Inovasi Dan Teknologi Informasi (SNITI) 3, 2016, vol. 3, pp. 393-400, doi: 10.17605/OSF.IO/HGMYC.

[15] S. R. Ningsih, I. S. Damanik, I. Gunawan, and W. Saputra, "Electre Dalam Menentukan Penerima Program Indonesia Pintar (PIP) Melalui Kartu Indonesia Pintar (KIP) (Studi Kasus: Sd Swasta Al - Washliyah Moho Kabupaten Simalungun )," vol. I, pp. 264-275, 2017.

[16] M. G. Sadewo, A. P. Windarto, and D. Hartama, "Penerapan Datamining Pada Populasi Daging Ayam Ras Pedaging Di Indonesia Berdasarkan Provinsi Menggunakan K-Means Clustering," InfoTekJar (Jurnal Nas. Inform. dan Teknol. Jaringan), vol. 2, no. 1, pp. 60-67, 2017.

[17] M. N. H. Siregar, "Neural Network Analysis With Backpropogation In Predicting Human Development Index ( HDI )

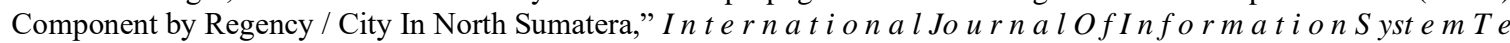
c h n o logy, vol. 1, no. 1, pp. 22-33, 2017.

[18] A. S. Ahmar et al., "Modeling Data Containing Outliers using ARIMA Additive Outlier (ARIMA-AO)," J. Phys. Conf. Ser., vol. 954, no. 1, 2018, doi: 10.1088/1742-6596/954/1/012010.

[19] A. Putrama and A. P. Windarto, "Analisis dalam menentukan produk bri syariah terbaik berdasarkan dana pihak ketiga menggunakan ahp,” CESS (Journal Comput. Eng. Syst. Sci., vol. 3, no. 1, pp. 60-64, 2018.

[20] P. P. P. A. N. W. F. I. R. H. Zer and A. P. Windarto, "Analisis Pemilihan Rekomendasi Produk Terbaik Prudential Berdasarkan Jenis Asuransi Jiwa Berjangka Untuk Kecelakaan Menggunakan Metode Analytic Hierarchy Process ( Ahp )," CESS (Journal Comput. Eng. Syst. Sci., vol. 3, no. 1, pp. 78-82, 2018.

[21] A. Darmawan, F. A. Mustika, and P. S. Informatika, "Sistem Pendukung Keputusan Metode Electre Pada Bauran Pemasaran (7P)," vol. 2, no. 2, pp. 184-192, 2017.

[22] W. Fauzi, P. S. Informatika, U. Jenderal, A. Yani, S. P. Keputusan, and R. Masalah, "Sistem pendukung keputusan penerima bantuan dana rutilahu dengan menggunakan metode ELECTRE 1," vol. 2016, no. Sentika, pp. 18-19, 2016.

[23] M. Mesran, G. Ginting, S. Suginam, and R. Rahim, "Implementation of Elimination and Choice Expressing Reality ( ELECTRE ) Method in Selecting the Best Lecturer (Case Study STMIK BUDI DARMA)," Int. J. Eng. Res. Technol., vol. 6, no. 2, NaN-2017, pp. 141-144, 2017.

[24] M. Mesran, R. Rusiana, and M. Sianturi, "Decision Support System for Termination of Employment using Elimination and Choice Translation Reality Method," J. Teknol. dan Sist. Komput., vol. 6, no. 4, p. 135, 2018.

[25] P. Sianturi, M. Mesran, P. Ramadhani, and N. W. Al-Hafiz, "SISTEM PENDUKUNG KEPUTUSAN PENENTUAN PENERIMA BANTUAN OPERASIONAL PENYELENGARAAN ( BOP ) PAUD ( PENDIDIKAN ANAK USIA DINI ) MENERAPKAN METODE ELECTRE ( STUDI KASUS: DINAS PENDIDIKAN KABUPATEN SIMALUNGUN )," KOMIK (Konferensi Nas. Teknol. Inf. dan Komputer), vol. I, no. 1, pp. 20-26, 2017.

[26] I. Saputra, S. I. Sari, and Mesran, "PENERAPAN ELIMINATION AND CHOICE TRANSLATION REALITY ( ELECTRE ) DALAM PENENTUAN KULKAS TERBAIK," KOMIK (Konferensi Nas. Teknol. Inf. dan Komputer), vol. I, pp. 295-305, 2017. 